\title{
DIVERSITY AND DISTRIBUTION OF ORIBATID MITES (ACARI:ORIBATIDA) IN A LOWLAND RAIN FOREST IN PERU AND IN SEVERAL ENVIRONMENTS OF THE BRAZILIANS STATES OF AMAZONAS, RONDÔNIA, RORAIMA AND PARÁ.
}

\author{
FRANKLIN, E., SANTOS, E. M. R. and ALBUQUERQUE, M. I. C. \\ Departament of Entomology, National Institute for Amazon Research, INPA, \\ CPEN, C. P. 478, CEP 69011-970, Manaus, AM, Brazil \\ Correspondence to: Elizabeth Franklin, INPA/CPEn, Avenida André Araújo, 2936, Petrópolis, C. P. 478, CEP 69011-970, \\ Manaus, AM, Brasil, e-mail: beth@inpa.gov.br
}

Received March 9, 2005 - Accepted April 12, 2005 - Distributed November 1, 2006

\begin{abstract}
We are summarizing the current state of knowledge of the diversity and distribution of oribatid mites in 26 environments in northern Brazil and of a rain forest in Peru. The published studies were mostly concentrated in Central Amazon. Only one report is a result from an agricultural polyculture. We are providing the first lists of species for savannas and for the Brazilian states of Roraima and Pará. Up to date, 146 species are definitively identified from a total of 444 taxa with 188 known genera, reinforcing the notion of a rich biodiverse area. The high number of 298 non-described species (morphospecies) clearly shows the inadequacy of the current taxonomic knowledge for the region. Most of the registers are from forest environments. In the soil from primary forests, we registered the highest diversity (54-155 species/morphospecies). Eighty-nine species were unique to primary forests, followed by 34 for savannas, 32 in trees, 10 in "igapó", 4 in caatinga, 3 in secondary forests, two in "várzea" and one in polyculture. Twenty genera were the most speciose. The species with the largest home ranges were Rostrozetes foveolatus, Scheloribates sp. A, and Galumna sp. A. Our numbers reflect the lack of taxonomists and show that the taxonomic knowledge must be improved for the region or we will continue to work with taxonomic resolution of Order or Family and a high percentage of morphospecies, which will probably be appropriate to the question being asked in each study, but not for a comparison among environments.
\end{abstract}

Keywords: Acari Oribatida, biological diversity, Neotropical, soil mites, arboriphilous mites.

\section{RESUMO}

\section{Diversidade e distribuição de ácaros oribatídeos (Acari:Oribatida) de uma floresta de terra firme do Peru e de diversos ambientes nos Estados brasileiros do Amazonas, de Rondônia, de Roraima e do Pará}

Sumarizamos o estado atual de conhecimento da diversidade e distribuição de ácaros oribatídeos em 26 ambientes do Norte do Brasil e em uma floresta do Peru. Os estudos publicados estão concentrados na Amazônia Central. A maioria dos registros é proveniente de florestas. Desses, somente um é resultado de estudo efetuado em campos agriculturais (policultivo). Fornecemos a primeira lista de espécies para savanas e para os Estados brasileiros de Roraima e do Pará. Até hoje, 146 espécies estão definitivamente identificadas de um total de 444 de taxa, totalizando 188 gêneros conhecidos, reforçando a noção de área ricamente biodiversa. O alto número de 298 espécies não descritas (morfo-espécies) mostra claramente que o conhecimento atual da taxonomia na região ainda é inadequado. No solo de floresta primária, registramos a maior diversidade (54 - 155 espécies/morfo-espécies). Oitenta e nove espécies foram coletadas apenas em florestas primárias, seguidas por 34 em savanas, 32 em árvores, 10 em igapó, 4 em caatinga, 3 em 
floresta secundária, duas em várzea e somente uma em policultivo. Vinte gêneros possuem o maior número de espécies. As espécies com maior amplitude de habitat foram Rostrozetes foveolatus, Scheloribates sp. A, e Galumna sp. A. Nossos números refletem a falta de taxonomistas e mostram que, caso o conhecimento taxonômico não seja incrementado na região, continuaremos a trabalhar com resolução taxonômica de Ordem ou de Família e com alta porcentagem de morfo-espécies, o que provavelmente poderá ser apropriado para a questão a ser respondida, mas não possibilitará uma comparação entre ambientes.

Palavras-chave: Acari Oribatida, Diversidade biológica, Neotropical, ácaros do solo, ácaros arborícolas.

\section{INTRODUCTION}

In primary forests, secondary growth and flooded forests of Central Amazon, the soil mesofauna, mainly Acari and Collembola, is the most abundant and frequent group. In Central Amazon, Brazil, the dominance of oribatid mites in relation to the total mesofauna community is over 50\% (Franklin et al., 1997a, b; Franklin et al., 2001a, b) and the known diversity is confirmed to be high, mainly in the soil of upland primary forests, varying from 71-95 collected species (Ribeiro \& Schubart, 1989; Franklin et al., 1997a, 1997b; Franklin et al., 2004). In Panguana, Peru, almost 200 species were registered in a lowland forest (Wunderle, 1985, 1992).

Some classification principles for the evaluation of arthropod community bioindicators are discussed by Straalen (1998), distinguishing life history, feeding type, function in the ecosystem and physiology. He also reinforces the use of multivariate statistics and ecophysiological classification. Hilty and Merelender (2000) list the baseline information (clear taxonomy, biology and life history studied, tolerance levels known, and correlation to ecosystem), local information (cosmopolitan distribution, and small home range size) and life history characteristics (early warning and functional range of stress, detectable trends, low variability, specialist, and easy to find and measure). Therefore, the value of any biodiversity analysis and the adequacy of conservation measures depend on the quality of basic taxonomic data (Valdecasas \& Camacho, 2003). Data on species' diversity are recognized as fundamental to the understanding of both natural and disturbed ecosystems, yet these data are meager for Acari in the Neotropics and limited by poor taxonomy (Behan-Pelletier et al., 1993). Noti et al. (2003) emphasizes the lack of data likely to support any assumption regarding the diversity of soil mites in the tropics. In spite of the considerable amount of literature to identify the species of the suborder Oribatida, there are nearly no genera, families and even super-families in the tropics that can be identified without problems. Many types and paratypes materials of the Neotropical species have to be rediscovered and redefined. For this purpose, it will be necessary to make samples in the respective regions where the specimens were sampled. Nevertheless, most of the type material described before the 1980's is not deposited at any museum in South America and some regions of samples will be impossible to localize (Franklin \& Woas, 1992; Franklin \& Woas, 2004).

A provisional checklist of 260 species and morphospecies collected in the Amazon region has already been published by Woas (2002). It is organized according to the morphological (and ontogenetic) organization and systematic group of Oribatida proposed by the author, including information concerning the ecology and distribution of the species. The list published by Woas (2002) was extracted from Beck (1971), Franklin (1994) and Ribeiro (1986) and compiled by L. Beck, S. Woas (Staatliches Museum für Naturkunde Karlsruhe, Karlsruhe), J. Adis (Max-Planck Institute, Plön) and Franklin, E (INPA, Manaus). In our study, we are amplifying the list, also following the systematic organization suggested by Woas (2002), having as a basis the results of published studies, and also adding new registers of species. Our objectives are: 1) to summarize the current state of knowledge regarding the diversity and distribution of oribatid mites in the region, and 2) to see the adequacy of the taxonomic knowledge in the region.

\section{METHODS}

The list of species and morphospecies recorded from the Brazilian state of Amazonas and 
from Panguana (Peru) is based on bibliographic references and compiled. In addition, the mites collected by the authors in the Brazilian states of Amazonas, Roraima, Rondonia and Pará were identified and compared with the results already published (Table 1, Appendix). The second author identified the species from the savanna on sandy soil in Pará. We excluded lists of species derived from studies where we could not clearly localize basic information, such as the correct name of the place of sampling or the type of vegetation. We also excluded the morphospecies identified at the level of family and the estimations of number of species for families.

Nomenclature and systematic organization of the list follows the morphological (and ontogenetic) organization and systematic group of Oribatida proposed by Woas (2002), who recommended that the establishment of well-defined higher taxa is a task which still requires intense revision. Therefore, instead of definitive higher taxa, he adopted only groups, largely conforming to Grandjean (1953), assigned to different levels of organization. Author names for genera, families and higher taxa are listed according to Balogh (1972), Balogh \& Balogh (1992) and Grandjean (1953, 1965, 1969). The names of the species are cited as the original publications, with small corrections in the orthography. Therefore, Subias (2004) and other monographs must be consulted to follow the possible changes occurred with the name of the species and genera. The morphospecies were included because of two common procedures among oribatidologists: 1) the identifications are restricted to "adult" mites (Noti et al., 2003), 2) the inclusion of morphospecies in most field analyses and 3) as knowledge of the affiliations of various species to the larger groups is sufficient, investigations based on those groups do not require exact knowledge of the taxonomical status of their species (Beck et al., 1997). The morphospecies names are listed following the sequence of the original publication, and we must be aware that, for example, Pergalumna sp. A of one specific environment cannot be the same species of another. The places and methodology of sampling are given in Table 1. However, original publications should be consulted for more specific information. In the results and discussion, we are dealing with a general overview of the faunistic partition of the studied environments, having as a basis the available data of the literature, independent of time, sampling method and experimental design of each study.

\section{RESULTS}

The studies were mostly concentrated in Central Amazonia, State of Amazonas in the neighborhood of the city of Manaus (Appendix). Since the initial published record of Oribatid mites species from Amazonia (Beck, 1971), approximately twelve authors have contributed to the knowledge of the Oribatid species in Amazonia, providing a list of species found from their results (Table 1). The samples were taken mostly in primary forests, followed by caatinga (locally called "campina"), savanna, white water flooded forest (locally called "várzea") dark water flooded forest (locally called "igapó"), secondary forest (locally called "capoeira") and the polyculture system. The records from Rondônia, Roraima and partially from Pará represent one sampling period. Except for the nylon mesh bag fauna, most records for Central Amazonia also correspond to one sampling period. In the primary forest (f5) of Reserva Florestal Adolpho Ducke (Ducke Reserve), the list of species that we have presented corresponds to a surveyed area of $24 \mathrm{~km}^{2}$, as a part of a large inventory covering 40,000 ha. The study in the savanna on sandy soil in Pará (s13) represents a large inventory of plots placed in an area of 30,000 ha.

Up to date, 146 species have definitively been identified from a total of 444 taxa, totalizing 188 known genera (Appendix). Twenty genera were the most speciose: Galumna (23 species), Scheloribates (15 species), Rostrozetes (10 species each), Pergalumna and Suctobelba (9 species each), Oppia and Phthiracarus (8 species each), Carabodes and Rhychoribates (7 species each), Eremobelba, Eremaeozetes and Truncopes (6 species each), Euphthiracarus, Eremulus, Charassobates, Licneremaeus, Benoibates, Lamellobates, Brachyoppia and Sternoppia (5 species each). The species with the largest home ranges was Rostrozetes foveolatus, Scheloribates sp. A, and Galumna sp. A, registered in more than $65 \%$ of the 26 environments, followed by Afronothrus incisivus neotropicus, Malaconothrus cf. neoplumosus, Cythermannia sp. A, Eremulus 
TABLE 1

Sampling places of edaphic and arboriphilous oribatid mites in Peru and Brazil*.

\begin{tabular}{|c|c|c|c|c|c|}
\hline $\begin{array}{c}\text { Place of } \\
\text { sampling }\end{array}$ & Region & $\begin{array}{l}\text { Number } \\
\text { of } \\
\text { reference }\end{array}$ & $\begin{array}{l}\text { Vegetation, soil } \\
\text { and places of } \\
\text { sampling }\end{array}$ & $\begin{array}{c}\text { Date, methods of sampling } \\
\text { and extraction }\end{array}$ & Authors \\
\hline \multirow[t]{2}{*}{$\begin{array}{l}\text { PERU } \\
\text { Panguana }\end{array}$} & \multirow{2}{*}{$\begin{array}{l}\text { Panguana at } \\
\text { Yuyapichis River, } \\
9^{\circ} 37^{\prime} \mathrm{S}, \\
74^{\circ} 56^{\prime} \mathrm{W}\end{array}$} & f1 & $\begin{array}{l}\text { Primary forest } \\
\text { (clay soil). }\end{array}$ & $\begin{array}{l}\text { May to October } 1984, \mathrm{n}=5 \text { samples } \\
\text { of } 1 / 9 \mathrm{~m}^{2} \text { each, extraction by Berlese } \\
\text { ( } 24 \text { funnels with } 0.5 \mathrm{~L} \text { of material). }\end{array}$ & \multirow[t]{2}{*}{$\begin{array}{l}\text { Wunderle, } \\
1985,1992\end{array}$} \\
\hline & & $\mathrm{t} 18$ & $\begin{array}{l}\text { Primary forest } \\
\text { (clay soil). }\end{array}$ & $\begin{array}{l}\text { May } 1984 \text { to October } 1984, \mathrm{n}=5 \text { tress } \\
\text { (ephiphyte, bark, lichens), extraction } \\
\text { by Berlese ( } 29 \text { funnels with } 0.5 \mathrm{~L} \text { of } \\
\text { material). }\end{array}$ & \\
\hline \multirow{3}{*}{$\begin{array}{l}\text { BRAZIL } \\
\text { Roraima } \\
(\mathrm{RR})\end{array}$} & \multirow{3}{*}{\begin{tabular}{|l|} 
Pacaraima mountain \\
complex, on the \\
border between \\
Brazil and Venezuela, \\
between $04^{\circ} 48^{\prime}$ to \\
$05^{\circ} 16^{\prime} \mathrm{N}$ and $60^{\circ}$ \\
$05^{\prime}$ to $60^{\circ} 44^{\prime} \mathrm{W}$
\end{tabular}} & $\mathrm{f} 2$ & $\begin{array}{l}\text { Primary forest } \\
\text { (clay soil). }\end{array}$ & \multirow{3}{*}{$\begin{array}{l}\text { October } 1995, \mathrm{n}=15 \text {, using split } \\
\text { corer }(7 \times 7 \mathrm{~cm}) 5 \mathrm{~cm} \text { depth in the } \\
\text { soil, and hand sampling of litter, } 1 \mathrm{~m}^{2}, \\
\text { extraction by Kempson apparatus }(\mathrm{E} . \\
\text { Franklin leg). }\end{array}$} & \multirow{9}{*}{ This study } \\
\hline & & s10 & $\begin{array}{l}\text { Arboreal Savanna, } \\
\text { also called Gallery } \\
\text { forest/Buriti line } \\
\text { (sandy soil). }\end{array}$ & & \\
\hline & & s11 & $\begin{array}{l}\text { Arboreal savanna } \\
\text { (sandy soil). }\end{array}$ & & \\
\hline \multirow[t]{2}{*}{$\begin{array}{l}\text { BRAZIL } \\
\text { Rondônia } \\
\text { (RO) }\end{array}$} & $\begin{array}{l}\text { Western port of the } \\
\text { Amazon Basin, } \\
\text { Ouro Preto do Oeste } \\
\text { Region, } 20 \mathrm{~km} \\
\text { from the city of } \\
\text { Texeiropolis, } 10^{\circ} \\
52^{\prime} \mathrm{S}, 62^{\circ} 07^{\prime} \mathrm{W} . \\
\end{array}$ & f8 & $\begin{array}{l}\text { Fragment of } \\
\text { disturbed forest } \\
(150 \times 180 \mathrm{~m} \text { (clay } \\
\text { soil). }\end{array}$ & $\begin{array}{l}\text { November } 1995, \mathrm{n}=15 \text {, using split } \\
\text { corer }(7 \times 7 \mathrm{~cm}) 5 \mathrm{~cm} \text { depth in the } \\
\text { soil , and hand sampling of litter, } \\
\text { extraction by Kempson apparatus (E. } \\
\text { Franklin leg). }\end{array}$ & \\
\hline & $\begin{array}{l}\text { Western port of the } \\
\text { Amazon Basin, } \\
\text { Ouro Preto do Oeste } \\
\text { Region, Martin } \\
\text { Pescador Reserve, } \\
60 \mathrm{~km} \text { from the city } \\
\text { of Urupa, } 11^{\circ} 07^{\prime} \mathrm{W}, \\
62^{\circ} 22^{\prime} \mathrm{W} \text {. }\end{array}$ & f3 & $\begin{array}{l}\text { Primary Forest } \\
\text { (clay soil). }\end{array}$ & $\begin{array}{l}\text { November } 1995, \mathrm{n}=15 \text {, using split } \\
\text { corer }(7 \times 7 \mathrm{~cm}) 5 \mathrm{~cm} \text { depth in the } \\
\text { soil, and hand sampling of litter, } 1 \mathrm{~m}^{2} \text {, } \\
\text { extraction by Kempson apparatus }(\mathrm{E} . \\
\text { Franklin leg). }\end{array}$ & \\
\hline \multirow[t]{3}{*}{$\begin{array}{l}\text { BRAZIL } \\
\text { Pará (PA) }\end{array}$} & \multirow{3}{*}{$\begin{array}{l}\text { Alter do Chão } \\
\text { Village ( } 2^{\circ} 22^{\prime} \mathrm{S}, 54^{\circ} \\
\left.37^{\prime} \mathrm{W}\right), 30 \mathrm{~km} \text { from } \\
\text { the city of Santarém. }\end{array}$} & $\mathrm{f} 4$ & $\begin{array}{l}\text { Primary Forest } \\
\text { (clay soil). }\end{array}$ & \multirow{2}{*}{$\begin{array}{l}\text { August } 1996, \mathrm{n}=15 \text {, using split corer } \\
(7 \times 7 \mathrm{~cm}) \text { introduced } 5 \mathrm{~cm} \text { depth } \\
\text { in the soil, extraction by Kempson } \\
\text { apparatus (E. Franklin leg). }\end{array}$} & \\
\hline & & s12 & Savana (clay soil) & & \\
\hline & & $\mathrm{s} 13$ & $\begin{array}{l}\text { Savanna } \\
\text { (sandy soil). }\end{array}$ & $\begin{array}{l}1998 \text { to } 2001, \text { Large inventory, } \\
\mathrm{n}=10 \text { in each plot of } 1 \mathrm{~km} \text { (total of } \\
40 \text { plots), split corer } 3.5 \times 3.5 \text { (E. M. } \\
\text { R. Santos and E. Franklin leg). Area } \\
\text { surveyed = } 30.000 \text { ha. }\end{array}$ & \\
\hline $\begin{array}{l}\text { BRAZIL } \\
\text { Amazonas } \\
(\mathrm{AM})\end{array}$ & $\begin{array}{l}\text { Manaus, Reserva } \\
\text { Florestal Adolpho } \\
\text { Ducke, } 2^{\circ} 53^{\prime} \mathrm{S} \\
59^{\circ} 59^{\prime} \mathrm{W} .\end{array}$ & f5 & $\begin{array}{l}\text { Primary Forest } \\
\text { (reaching a } \\
\text { gradient of clay } \\
\text { and sandy soils). }\end{array}$ & $\begin{array}{l}\text { September } 2001 \text { to April 2002, Large } \\
\text { inventory, } 3 \text { trails } 8 \mathrm{~km} \text { long, forming } \\
\text { a network of } 24 \mathrm{~km}^{2}, 24 \text { plots of } \\
250 \mathrm{~m} \text { separated } 1 \mathrm{~km} \text { from each } \\
\text { other, } \mathrm{n}=5 \text { at each plot, extraction by } \\
\text { Berlese-Tullgren (E. Franklin, R. L. } \\
\text { Guimarães, E. P. Fagundes, and E. D. } \\
\text { L. Soares leg). }\end{array}$ & \\
\hline
\end{tabular}


TABLE 1

Continued..

\begin{tabular}{|c|c|c|c|c|c|}
\hline $\begin{array}{c}\text { Place of } \\
\text { sampling }\end{array}$ & Region & $\begin{array}{l}\text { Number } \\
\text { of } \\
\text { reference }\end{array}$ & $\begin{array}{l}\text { Vegetation, soil } \\
\text { and places of } \\
\text { sampling }\end{array}$ & $\begin{array}{c}\text { Date, methods of sampling } \\
\text { and extraction }\end{array}$ & Authors \\
\hline \multirow[t]{9}{*}{$\begin{array}{l}\text { BRAZIL } \\
\text { Amazonas } \\
(\mathrm{AM})\end{array}$} & $\begin{array}{l}\text { Manaus, Reserva } \\
\text { Florestal Adolpho } \\
\text { Ducke, } 2^{\circ} 53 \text { ' S, } 59^{\circ} \\
59^{\prime} \text { W. Sampling sites } \\
\text { according to Beck } \\
(1971): 1,12,13,50 .\end{array}$ & f6 & Primary forest & $\begin{array}{l}\text { November } 1965 \text { to January } 1966, \\
\text { samples of } 500 \mathrm{~cm} \text { of litter and soil, } \\
\text { Berlese-Tullgren. }\end{array}$ & \multirow[t]{5}{*}{ Beck, 1971} \\
\hline & $\begin{array}{l}\text { Manaus, Reserva } \\
\text { Florestal Adolpho } \\
\text { Ducke, 2॰ 53' S, 59 } \\
\text { 59’ W. Sampling sites } \\
\text { according to Beck } \\
(1971): 3,11,32,33 .\end{array}$ & f7 & $\begin{array}{l}\text { "Palmetum" } \\
\text { (transitive habitat } \\
\text { in brook valleys, } \\
\text { consisting of } \\
\text { primary forest, } \\
\text { determinated by } \\
\text { palm trees). }\end{array}$ & $\begin{array}{l}\text { November } 1965 \text { to January } 1966, \\
\text { samples of } 500 \mathrm{~cm} \text { of litter and soil, } \\
\text { Berlese- Tullgren. }\end{array}$ & \\
\hline & $\begin{array}{l}\text { Manaus, Reserva } \\
\text { Florestal Adolpho } \\
\text { Ducke, } 2^{\circ} 53^{\prime} \text { S, } 59^{\circ} \\
59^{\prime} \text { W. Sampling sites } \\
\text { according to Beck } \\
\text { (1971): 4-6, 22, 23, } 31 .\end{array}$ & c9 & $\begin{array}{l}\text { "Campina"or } \\
\text { Caatinga. }\end{array}$ & $\begin{array}{l}\text { December } 1965 \text { to February } 1966, \\
\text { samples of } 500 \mathrm{~cm} \text { of litter and soil, } \\
\text { Berlese- Tullgren. }\end{array}$ & \\
\hline & $\begin{array}{l}\text { Neighbourhood of } \\
\text { Manaus. Sampling } \\
\text { sites according to Beck } \\
(1971): 14,16,18,20, \\
39,40,64,65,66 . \\
\end{array}$ & v16 & $\begin{array}{l}\text { "Várzea", } \\
\text { including } \\
\text { submersed } \\
\text { material. }\end{array}$ & $\begin{array}{l}\text { February to May 1966. Samples } \\
\text { of } 500 \mathrm{~cm} \text { of litter and soil, hand } \\
\text { sampling, Berlese-Tullgren and } \\
\text { Exhaustor. }\end{array}$ & \\
\hline & $\begin{array}{l}\text { Neighbourhood of } \\
\text { Manaus. Sampling } \\
\text { sites according to } \\
\text { Beck }(1971): 7-10 ; \\
15 ; 25-30 ; 36-38 ; \\
47-49 ; 52-63 ; 72-77 .\end{array}$ & i14 & $\begin{array}{l}\text { Igapó (Solimões } \\
\text { River), including } \\
\text { submersed } \\
\text { material. }\end{array}$ & $\begin{array}{l}\text { January to May 1966, samples of } 500 \\
\text { cm of litterand soil, hand sampling, } \\
\text { Berlese-Tullgren and Exhaustor. }\end{array}$ & \\
\hline & \multirow[t]{2}{*}{$\begin{array}{l}30 \mathrm{~km} \text { from the city } \\
\text { of Tarumã Mirim } \\
\text { River, } 3^{\circ} 01^{\prime} \mathrm{S}, 60^{\circ} \\
10^{\prime} \mathrm{W} .\end{array}$} & i15 & $\begin{array}{l}\text { Inundated forest of } \\
\text { "igapo"(clayish- } \\
\text { sand soil). }\end{array}$ & $\begin{array}{l}\text { September } 1981, \mathrm{n}=6 \text {, six months } \\
\text { during the terrestrial phase, split } \\
\text { corer (steel cylinder, diameter } 21 \\
\mathrm{~cm} \text { ), extraction by Kempson Method, } \\
14 \mathrm{~cm} \text { deeper in the soil. }\end{array}$ & $\begin{array}{l}\text { Franklin, } \\
1994 ; \\
\text { Franklin } \\
\text { et al., } \\
1997 \mathrm{a}, \mathrm{b} \\
\end{array}$ \\
\hline & & $\mathrm{t} 19$ & $\begin{array}{l}\text { Inundated forest of } \\
\text { "igapo"(clayish- } \\
\text { sand soil). }\end{array}$ & $\begin{array}{l}\text { February } 1989 \text { to January 1990. In } \\
\text { Barks of Aldina latifolia var. latifolia } \\
\text { and Mora paraensis trees, ( } \mathrm{n}=5 \text {, } \\
196 \mathrm{~cm}^{2} / \mathrm{month} \text { ), Bark-brushing Method. }\end{array}$ & $\begin{array}{l}\text { Franklin, } \\
\text { 1994; } \\
\text { Franklin } \\
\text { et al., } 1998\end{array}$ \\
\hline & \multirow[t]{2}{*}{$\begin{array}{l}30 \mathrm{~km} \text { from the city } \\
\text { of Manaus, Solimões } \\
\text { River, Marchantaria } \\
\text { Island, } 3^{\circ} 15^{\prime} \mathrm{S}, 59^{\circ} \\
58^{\prime} \mathrm{W} .\end{array}$} & v17 & $\begin{array}{l}\text { Inundated forest of } \\
\text { "várzea" riverborn } \\
\text { sediments, } \\
\text { montmorillonite. }\end{array}$ & $\begin{array}{l}\text { October } 1981, \mathrm{n}=6.6 \text { months during } \\
\text { the terrestrial phase, split corer (steel } \\
\text { cylinder, diameter } 21 \mathrm{~cm} \text { ), extraction } \\
\text { by Kempson Method, } 3.5 \mathrm{~cm} \text { deeper } \\
\text { in the soil. }\end{array}$ & $\begin{array}{l}\text { Franklin, } \\
1994 ; \\
\text { Franklin } \\
\text { et al., } \\
1997 \mathrm{a}, \mathrm{b} \\
\end{array}$ \\
\hline & & $\mathrm{t} 20$ & $\begin{array}{l}\text { Inundated forest of } \\
\text { "várzea" riverborn } \\
\text { sediments, } \\
\text { montmorillonite. }\end{array}$ & $\begin{array}{l}\text { February/1989 to January/1990. In } \\
\text { bark of Pseudobombax munguba and } \\
\text { Macrolobium acaciaefolium trees, (n } \\
=5,196 \mathrm{~cm}^{2} / \text { month), Bark-brushing } \\
\text { Method. }\end{array}$ & $\begin{array}{l}\text { Franklin, } \\
1994 ; \\
\text { Franklin } \\
\text { et al., } 1998\end{array}$ \\
\hline
\end{tabular}


TABLE 1

Continued..

\begin{tabular}{|c|c|c|c|c|c|}
\hline $\begin{array}{c}\text { Place of } \\
\text { sampling }\end{array}$ & Region & $\begin{array}{l}\text { Number } \\
\text { of } \\
\text { reference }\end{array}$ & $\begin{array}{l}\text { Vegetation, soil } \\
\text { and places of } \\
\text { sampling }\end{array}$ & $\begin{array}{c}\text { Date, methods of sampling } \\
\text { and extraction }\end{array}$ & Authors \\
\hline \multirow{6}{*}{$\begin{array}{l}\text { BRAZIL } \\
\text { Amazonas } \\
(\mathrm{AM})\end{array}$} & \multirow{3}{*}{$\begin{array}{l}60 \mathrm{~km} \text { from the city } \\
\text { Manaus, } 2^{\circ} 53^{\prime} \mathrm{S} \text {, } \\
59^{\circ} 59^{\prime} \mathrm{W} .\end{array}$} & $\mathrm{f} 21$ & $\begin{array}{l}\text { Primary forest } \\
\text { (clay Soil) }\end{array}$ & \multirow{3}{*}{$\begin{array}{l}\text { January } 1980 \text {, litterbags ( } 1 \mathrm{~mm} \text { mesh } \\
\text { size) containg leaves of Clitoria } \\
\text { racemosa, sampling done after } 15 \text {, } \\
30,60,90,120 \text { and } 150 \text { days from } \\
\text { the beginning of the experiment, } \\
\text { extration by Berlese-Tullgren. }\end{array}$} & \multirow{3}{*}{$\begin{array}{l}\text { Ribeiro, } \\
1986 ; \\
\text { Ribeiro \& } \\
\text { Schubart, } \\
1989\end{array}$} \\
\hline & & $\mathrm{f} 22$ & $\begin{array}{l}\text { Primary forest } \\
\text { (sandy Soil) }\end{array}$ & & \\
\hline & & sf24 & $\begin{array}{l}\text { Secondary forest, } \\
3 \text { years old (clay } \\
\text { soil) }\end{array}$ & & \\
\hline & \multirow{3}{*}{$\begin{array}{l}29 \mathrm{~km} \text { from the city } \\
\text { of Manaus, } 2^{\circ} 45^{\prime} \mathrm{S} \text {, } \\
60^{\circ} 15^{\prime} \mathrm{W} .\end{array}$} & $f 23$ & $\begin{array}{l}\text { Primary forest } \\
\text { (clay Soil) }\end{array}$ & \multirow{3}{*}{$\begin{array}{l}\text { April 1998, litterbags (20 } \mu \mathrm{m} \text {, } \\
250 \mu \mathrm{m} \text {, and } 1000 \mu \mathrm{m} \text { mesh size }) \\
\text { containing leaves of Vismia sp., } \\
\text { sampling done after } 25,58,111,174 \text {, } \\
278 \text { and } 350 \text { days from the begining } \\
\text { of the experiment, extraction by } \\
\text { Berlese-Tullgren }\end{array}$} & \multirow{3}{*}{$\begin{array}{l}\text { Hayek, } \\
2000 ; \\
\text { Fraklin } \\
\text { et al., } 2004\end{array}$} \\
\hline & & sf 25 & $\begin{array}{l}\text { Secundary forest } \\
\text { (clay Soil) }\end{array}$ & & \\
\hline & & p26 & $\begin{array}{l}\text { Policulture system } \\
\text { (clay soil) }\end{array}$ & & \\
\hline
\end{tabular}

*The environments are organized according to the region of sampling in Peru (Panguana) and Brazil (Roraima - RR, Rondônia - RO, Pará - PA and Amazonas - AM).

translamellatus, Pergalumna sp. A, Eremulus sp A (54\%), Eohypochthonius sp. A, Eremaeozetes sp. A, Galumna sp. B and Lamellobates sp. A (50\%), Teleiolioides sp. A, Tectocepheus sp. A, Eremobelba sp. A, Rhynchoribates sp. A, Oppia sp. A, Archegozetes longisetosus and Truncozetes mucronatus (38 to 46\%) (Appendix).

A total of 187 species $(42.1 \%)$ had only one register of occurrence. Considering the eight different types of vegetation and/or substratum (primary forest, campina, savanna, "igapó", "várzea", trees, secondary forest and polyculture), almost $48.9 \%$ (217) were unique to a particular environment, even though they had more than one register of occurrence. A percentage of $56.2 \%$ (122) were registered only in primary forests (including natural and artificial substrata), followed by 37 species in the savannas, 35 on trees, 12 in "igapó", 4 in the secondary forest, 3 in the caatinga, two in the "várzea", and two in a polyculture system.

The maximum number of species (and/or morphospecies) registered in the primary forest of Manaus and Peru (f1, f5, f6 and f7), oscillated between 54 and 155 (Table 2). In combined samples of soil and trees (f1 and t18), this number increased to 196 in Peru. Comparatively, the numbers registered for the primary forest in Roraima (f2) and Rondônia (f3) dropped to 37-38. In a disturbed primary forest in Rondônia (f8), the number of species dropped even more to 25 . The diversity in the savanna (s10 to s13) varied from 15 to 67 species. Comparing the flooded forests with the majority of the primary forests, the diversity was reduced to 33-45 species in "igapó" (i14 and i15) and to 13-35 species in "várzea" (v16 and v17). Taking into consideration that the survey was made for a period of six months, the registers for the "várzea" were very low, mainly for trees. The number of species sampled on trees in Amazonas (4-22) is not comparable to the number registered in Peru (120 species), because in the states of Amazonas the inventories were done in a flooded forest and the epiphytes were not included. The maximum number of species sampled in nylon mesh-bags (76 species) in Central Amazonia were registered in a primary forest (f23), dropping to 55-60 in a secondary forest (sf24 and sf25) and to 50 in a polyculture system (p26).

\section{DISCUSSION}

The studies already published provide an initial base for future research on Oribatid mites. In their respective lists of species, some of these 
TABLE 2

Total number of species and morphospecies of edaphic and arboriphilous oribatid mites (Acari:Oribatida) registered in Peru and Brazil. The abbreviations of the regions refer to the Brazilian States of Amazonas (AM), Pará (PA), Roraima (RR) and Rondônia (RO)*.

\begin{tabular}{|c|c|c|c|c|c|c|}
\hline $\begin{array}{c}\text { Type of } \\
\text { substratum }\end{array}$ & Vegetation (symbol) & $\begin{array}{c}\text { Number of } \\
\text { reference }\end{array}$ & Region & \begin{tabular}{|c|} 
Lower \\
Oribatida \\
\end{tabular} & \begin{tabular}{|c|} 
Higher \\
Oribatida \\
\end{tabular} & Total \\
\hline \multirow[t]{20}{*}{ Natural } & \multirow{7}{*}{$\begin{array}{l}\text { Non-disturberd primary forests } \\
\text { forests (f) }\end{array}$} & $\mathrm{f} 1$ & PERU & 33 & 122 & 155 \\
\hline & & $\mathrm{f} 2$ & $\mathrm{RR}$ & 16 & 21 & 37 \\
\hline & & $\mathrm{f3}$ & $\mathrm{RO}$ & 12 & 26 & 38 \\
\hline & & $\mathrm{f} 4$ & $\mathrm{PA}$ & 12 & 39 & 51 \\
\hline & & f5 & $\mathrm{AM}$ & 16 & 41 & 57 \\
\hline & & f6 & $\mathrm{AM}$ & 20 & 58 & 78 \\
\hline & & $\mathrm{f7}$ & $\mathrm{AM}$ & 11 & 43 & 54 \\
\hline & Disturbed primary forest (f) & f8 & $\mathrm{RO}$ & 7 & 18 & 25 \\
\hline & Caatinga (c) & c9 & $\mathrm{AM}$ & 13 & 42 & 55 \\
\hline & \multirow[t]{4}{*}{ Savanna (s) } & $\mathrm{s} 10$ & $\mathrm{RR}$ & 4 & 11 & 15 \\
\hline & & s11 & $\mathrm{RR}$ & 8 & 19 & 27 \\
\hline & & s12 & $\mathrm{PA}$ & 6 & 19 & 25 \\
\hline & & s13 & PA & 18 & 49 & 67 \\
\hline & \multirow[t]{2}{*}{ "Igapó" (i) } & i14 & AM & 20 & 25 & 45 \\
\hline & & i15 & $\mathrm{AM}$ & 9 & 24 & 33 \\
\hline & \multirow[t]{2}{*}{ "Várzea" (v) } & v16 & AM & 11 & 24 & 35 \\
\hline & & v17 & $\mathrm{AM}$ & 3 & 10 & 13 \\
\hline & \multirow[t]{3}{*}{ Trees ( $(\mathrm{t})$} & $\mathrm{t} 18$ & PERU & 14 & 106 & 120 \\
\hline & & $\mathrm{t} 19$ & $\mathrm{AM}$ & 2 & 20 & 22 \\
\hline & & $\mathrm{t} 20$ & AM & 0 & 4 & 4 \\
\hline \multirow[t]{6}{*}{ Artificial } & \multirow[t]{3}{*}{ Primary forest (f) } & $\mathrm{f} 21$ & AM & 11 & 56 & 67 \\
\hline & & $\mathrm{f} 22$ & $\mathrm{AM}$ & 15 & 58 & 73 \\
\hline & & $\mathrm{f} 23$ & $\mathrm{AM}$ & 23 & 53 & 76 \\
\hline & \multirow[t]{2}{*}{ Secondary forest (sf) } & sf24 & $\mathrm{AM}$ & 9 & 46 & 55 \\
\hline & & sf 25 & $\mathrm{AM}$ & 20 & 47 & 67 \\
\hline & Polyculture system (p) & $\mathrm{p} 26$ & AM & 20 & 43 & 63 \\
\hline
\end{tabular}

*The environments are organized according to the type of vegetation of the samples made on natural and artificial substrata (nylon mesh-bag fauna).

studies were used to review the morphological organization and systematic groups of Oribatida made by Woas (2002), who also published a provisional checklist of adult oribatid mites (described species and non-described species) occurring in environments of the Amazon region. Otherwise, our review demonstrates the lack of and the need for information on the Oribatid mites, as the information is mostly concentrated in Central Amazonia. The city of Manaus and the city of São Paulo are the locations of the major centers of studies of Oribatid mites in Brazil. In contrast, almost nothing is known from other Brazilian regions of the northeast, central-east, and south. Thus, it is clear that this reflects collection and identification efforts in both regions, rather than real differences in regional diversity, as already registered by Culik \& Zeppelini Filho (2003) for the Collembola fauna in Brazil. Most of the species are known from forest environments. It is noted that with the exception of one environment (p26), no one has reported results of samples from agricultural field sites. We are also providing the first records for savanna, and for the Brazilian states of Roraima, Rondônia and Pará. 
The arboriphilous oribatid fauna found on trees from a primary forest in Peru (Panguana) is at least as rich as other tropical forest environments (Wunderle 1992). The same pattern was found in northern Venezuela (northern part of South America), where the richest fauna was associated with bromeliads (67 species), followed by litter (63 species) and soil (27 species) (Behan-Pelletier et al., 1993). Two registers for the oribatid fauna found on trees in Amazonas are available (Franklin et al., 1998), but only for flooded forests of "várzea" and "igapó", and the results do not follow the same pattern detected above, as more species were found on the soil of both forests. The differences were caused mainly by the methodology of sampling, as the epiphytes were not included in the sampling method from the inventories of Amazonas.

Only in the savanna under sandy soil in Pará (s13), the large-scale period of sampling and the huge surveyed area ensures that the number of registered species (67) probably represents $60-70 \%$ of the total diversity of the area, and it expected to increase to an estimated number of 90-100 species. The register of 67 species is lower than the registers of Noti et al. (2003) with 105 species collected in a tropical savanna from High Katanga (Congo, Africa). Otherwise, they registered 94 species in climax dense dry forest ("muhulu"), and 86 species in woodland ("miombo"), that are almost similar to the average registers in primary forests of Central Amazonia.

Only on the species level is it possible to look for differential species that are restricted to separate localities, thus making it possible to analyse (Beck et al., 1997). Therefore, compared to the number of described species, the number of morphospecies registered in our list is very high (298 species), corresponding to $67 \%$ in relation to the total registered, clearly showing the inadequacy of the current taxonomic knowledge for the region. Otherwise, our numbers also reflect the lack of taxonomists and the need of studies to determine the species composition of the communities of oribatid mites in Brazil. Although the morphospecies in our registers can not be comparable between environments, and that the most speciose genera corresponds to only $10 \%$ of the total of genera identified, we consider our numbers to be a close approximation of the real diversity of soil oribatid mites in the sites investigated. Therefore, this diversity is also closely related to the methods of sampling and aim of each study. Other aspects make the faunistic analysis of this group difficult, mainly in the Amazon region: 1) the punctual samples and only one amostral period, not representing the spatial scale of the environment in question; 2) the variability of methods of sampling and extraction; 3 ) the great distance between the investigated site, even though these soil mesofauna studies are concentrated mainly in Central Amazon; and 4) the continental size and biodiverse complexity of the region.

The 444 species registered in our estimation, reinforces the notion of a richly biodiverse area. Therefore, we cannot establish any level or "rarity" for the large percentage of species (42\%) with only one register of occurrence, and also the large percentage of species registered only for a single environment (48.9\%). In Venezuela, a much larger percentage $(65 \%)$ of unique species to a particular ecosystem was registered (Behan-Pelletier et al., 1993).

A percentage of $56.2 \%$ (122) was registered only in primary forests (including natural and artificial substrata), followed by 37 species in the savannas, 35 on trees, 12 in "igapó", 4 in the secondary forest, 3 in the caatinga, two in the "várzea", and two in a polyculture system. Hence, this pattern of unique species follows a gradient of reduction from the non-disturbed (primary forest) toward disturbed environments.

Rather than focusing on a single species, many soil zoologists have attempted to measure the diversity of the community as a whole, but simple indices have not proven to be very useful (Straalen, 1998). The concept of "taxonomic sufficiency", the identification of organisms only to a level of taxonomic resolution sufficient to fulfil the objectives of a study (Ellis, 1985), has received little attention in ecological studies of terrestrial invertebrates (Pik et al., 1999). This tool would make the reduction possible of the number of scientist-hours spent on processing the samples, which increases dramatically for smaller-bodied taxa (Lawton et al., 1998), by not including unnecessary and even inappropriate species (Hilty \& Merelender, 2000), as the most obvious requirement for a good indicator group for species richness is that it mirrors well the total number of species (Olsgard et al., 2003). In poorly known environments, the use of rough taxonomic resolution is still premature (Terlizzi et al., 2003), 
and this is certainly the case of the Amazon region. As the number of morphospecies of oribatid mites registered in our list corresponds to $67 \%$ in relation to the total registered taxa, and considering their mega diversity, we are far from having a good taxonomic knowledge of this group in the region.

Our results reinforce the alert raised by Maurer (2000), in a way that the process of care and nurturing of taxonomic specialists is a necessary step to resolve the problem of taxonomical accuracy necessary to solve the predicament. A detailed inventory, even from one area, of the impacts of tropical forest modification and disturbance on biodiversity will require a huge scientific effort, far exceeding anything attempted so far anywhere in the world (Lawton et al., 1998). Perhaps a general recommendation would be that $10 \%$ of the time of any ecological study of the soil fauna should be devoted to the development of taxonomic basis of one of the groups of animals that comprises that soil community (Usher, 1988), or end up working with just numbers in rough taxonomic resolution (Valdecasas \& Camacho, 2003), and skilled eyes are needed to go on studying the richness for the soil (Andre et al., 2001). Otherwise, we will continue to work with rough taxonomic resolution and/or a high percentage of morphospecies, which will probably be appropriate to the question being asked in each study, but not for a comparison among the environments being investigated.

Acknowledgments - Financial support came from PNOPG, 550409/01-7, "Populações e comunidades de invertebrados do solo da Reserva Adolpho Ducke, Manaus, AM", PPD-G7 6400-0021 "As interações entre savanas e florestas na Amazonia Central e sua importância para a biodiversidade" grant to R. Cintra, and "Ácaros em Pomar Comercial de Citros no Município de Manaus, AM, com ênfase nas Famílias Tenuipalpidae e Eriophyidae" grant from FAPEAM/PIPT to E. Franklin, and a "Bolsa de Produtividade em Pesquisa" grant from CNPq to E. Franklin.

\section{REFERENCES}

ANDRE, H., DUCARME, X., ANDERSON, J., CROSSLEY, D., HOEHLER, H., PAOLETTI, M., LEBRUN, P. 2001. Skylled eyes are needed to go on studying the richness for the soil. Nature 409, 761

BALOGH, P., 1972, The oribatid genera of the world. Acad. Kiado, Budapest. 188p.

BALOGH J. \& BALOGH, P., 1992, The oribatid mite genera of the world. Vols. 1, 2. Hung. Nat. Hist. Mus. Press, Budapest. 263 and 375 pp.
BECK, L., 1971, Bodenzoologische Gliederung und Charakterisierung des amazonischen Regenwaldes, Amazoniana, 3(1):69-132.

BECK, L., WOAS, S. \& HORAK, F., 1997, Taxonomische Ebenen als Basis der Bioindikation - Fallbeispiele aus der Gruppe der Oribatiden (Acari). Abh. Ber. Naturkundemus, Görlitz 69(2): 67-85

BEHAN-PELletier, V., PAOLETT, M. G., BISSET, B. STINNER, B. R., 1993, Oribatid mites of forest habitat in northern Venezuela. Trop. Zool., 1:39-54.

CULIK, M. P. \& ZEPPELINI FILHO, D. 2003. Diversity and distribution of Collembola (Arthropoda: Hexapoda) of Brazil. Biodivers. Conserv. 12: 1119-1143.

ELLIS, D., 1985, Taxonomic sufficiency in pollution assessment. Max. Pollut. Bull. 16:459.

FRANKLIN, E., 1994, Ecologia de oribatídeos (ACARI: ORIBATIDA) em florestas inundáveis da Amazônia Central. $\mathrm{Ph}$. D. Thesis, INPA/Amazon University, Manaus, 266p.

FRANKLIN, E., WOAS, S. Some oribatid mites of the family Oppiidae (Acari; Oribatei) from Amazonia. Andrias, 9: 5-56, 1992.

FRANKLIN, E., WOAS, S., 2004, Oribatídeos (Acari: Oribatida) como elementos e grupos faunísticos em solos da região Neotropical, pp. 83-90. In: História natural, ecologia e conservação de algumas espécies de plantas e animais da Amazônia. EDUA/INPA/FAPEAM, Série Biblioteca Científica da Amazônia.

FRANKLIN, E. N., ADIS, J. \& WOAS, S., 1997a, The Oribatid Mites. pp. 331-349. In: JUNK, W. J. (ed.), Central Amazonian river floodplains: ecology of a pulsing system. Springer-Verlag, Berlin, Heidelberg,

FRANKLIN, E. N., SCHUBART, H. O. R. \& ADIS, J. U., 1997b, Ácaros (ACARI: ORIBATIDA) Edáficos de duas florestas inundáveis da Amazônia Central: Distribuição vertical, abundância e recolonização do solo após a inundação. Rev. Bras. Biol., 57(3): 501-520.

FRANKLIN, E. N., WOAS, S., SCHUBART, H. O. R. \& ADIS, J., 1998, Ácaros oribatídeos (Acari:Oribatida) arborícolas de duas florestas inundáveis da Amazônia Central. Rev. Bras. Biol., 58(2): 317-335.

FRANKLIN, E., MORAIS, J. W., SANTOS, E. M. R., 2001a, Density and biomass of Acari and Collembola in primary forest, secondary regrowth and polycultures in central Amazonia. Andrias, 15(1): 141-154.

FRANKLIN, E. N, GUIMARÃES, R. L., ADIS, J. U. \& SCHUBART, H. O. R., 2001b, Resistência à submersão de ácaros (Acari: Oribatida) terrestres de florestas inundáveis e de terra firme na Amazônia Central em condições experimentais de laboratório. Acta. Amazonica, 31(2): 285-298.

FRANKLIN, E., HAYEK, T., FAGUNDES, E. P. \& SILVA, L. L., 2004, Oribatid mites (Acari: Oribatida) contribution to decomposition dynamic of lest litter in primary forest, second growth and policulture in the Central Amazon. Rev. Bras. Biol., 64(1): 59-72.

GRANDJEAN, F., 1953, Essai de classification des Oribates (Acariens). Bull. Soc. Zool. France, 78:421-446. 
GRANDJEAN, F., 1965, Complément à mon travail de 1953 sur la classification des Oribates. Acarologia, 7: 713-734.

GRANDJEAN, F., 1969, Considération sur le classement des Oribates. Leurs division en 6 groupes majeurs. Acarologia, 10: $127-153$.

HAYEK, T., 2000, Ácaros do solo (ACARI: ORIBATIDA): diversidade, abundância e biomassa na decomposição de serapilheira em parcelas de floresta primária, capoeiras e policultivo da Amazônia Central. MSc. Thesis. Manaus, INPA, 93p.

HILTY, J. \& MERENLENDER, A., 2000, Faunal indicator taxa selection for monitoring ecosystem health. Biol. Conserv., 92: 185-197.

LAWTON, J. H., BIGNELL, D. E., BOLTON, B., BLOERNERS, G. F., EGGLETON, P., HAMMOND, P. M., HODDA, M., HOLT, R. D., LARSEN, T. B., MAWDSLEY, N. A., STORK, N. E., SRIVASTAVA, D. S. \& WATT, A. D., 1998, Biodiversity inventories, indicator taxa and effects of habitat modification in tropical forest. Nature, 391(1): 72-75.

MAURER, D., 2000, The dark side of taxonomic sufficiency (TS). Mar. Pollut. Bull., 40(2): 98-101.

NOTI, M. I., ANDRÉ, H. W., DUCARME, X. \& LEBRUN, P., 2003, Diversity of soil oribatid mites (Acari:Oribatida) from High katanga (Democratic Republic of Congo): a multiscale and multifactor approach. Biodivers. Conserv., 12: 767-785.

OLSGARD, F. BRATTEGARD, T. \& HOLTHE, T. 2003. Polychates as surrogates for marine biodiversity. Biodiversity and Conservation, 12: 1033-1049.

PIK, A. J., OLIVER, I. \& BEATTIE, A., 1999, Taxonomic sufficiency in ecological studies of terrestrial invertebrates. Aust. Jour. of Ecol., 24: 555-562.

RIBEIRO, E. F., 1986, Oribatídeos (ACARI:ORIBATIDA) colonizadores de folhas em decomposição sobre o solo de três sítios florestais da Amazônia Central. MSc. Thesis. Manaus, INPA, 178p.

RIBEIRO, E. F. \& SCHUBART, H. O. R., 1989, Oribatídeos (ACARI: ORIBATIDA) colonizadores de folhas em decomposição sobre o solo de três sítios florestais da Amazônia Central. Bol. Mus. Emílio Goeldi, 5(2): 243-276.

STRAALEN, N. M., 1998, Evaluation of bioindicator systems derived from soil arthropod communities. App. Soil Ecol., 9: 429-437.

SUBIAS, L. S., 2004, Listado Sistemático, Sinonímico y Biogeográfico de los Ácaros Oribátidos (Acariformes: Oribatida) del Mundo (Excepto fósiles). Graellsia, 60(número extraordinario): 3-305.

TERLIZZI, A., BEVILACQUA, S., FRANSCHETTI, S. \& BOERO, F., 2003, Taxonomic sufficiency and the increasinf insufficiency of taxonomic expertise. Mar. Pollut. Bull., 46: $556-561$

USHER, M. B., 1988, Soil invertebrates: a review of species populations, communities, modeling and conservation with special reference to the African Continent. Revue de Zoologie Africaine (Journal of African Zoology) pp. 285-300.

VALDECASAS, A. G. \& CAMACHO, A. I., 2003, Conservation to the rescue of taxonomy. Biodivers. Conserv., 12: 1113-1117.

WOAS, S., 2002, Acari. In: Adis J. (ed.): Amazonian Arachnida and Myriapoda. Pensoft, Sofia-Moscow. pp. 21-291.

WUNDERLE, I., 1985, Ein faunistich-ökologischer vergleich der Baum- und Bodenbewohnenden Oribatiden (Acari) im Tieflanderegenwald von Panguana, Peru. M. Sc. Thesis. Universität Karlsruhe, 103p.

WUNDERLE, I., 1992, Die Baum- und bodenbewohnenden Oribatiden (Acari) im Tief-landeregenwald von Panguana, Peru. Amazoniana, 17(1): 119-142. 


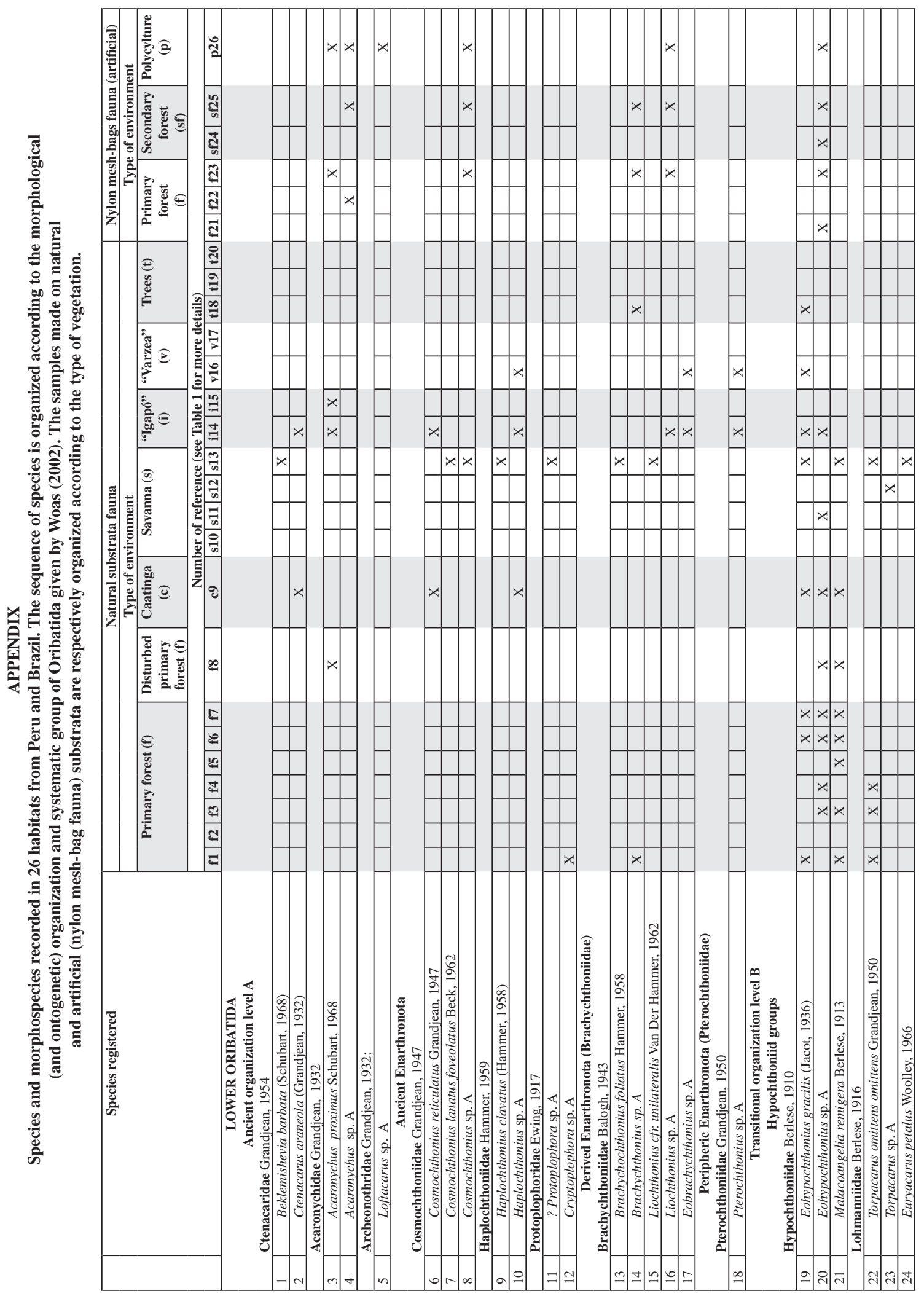




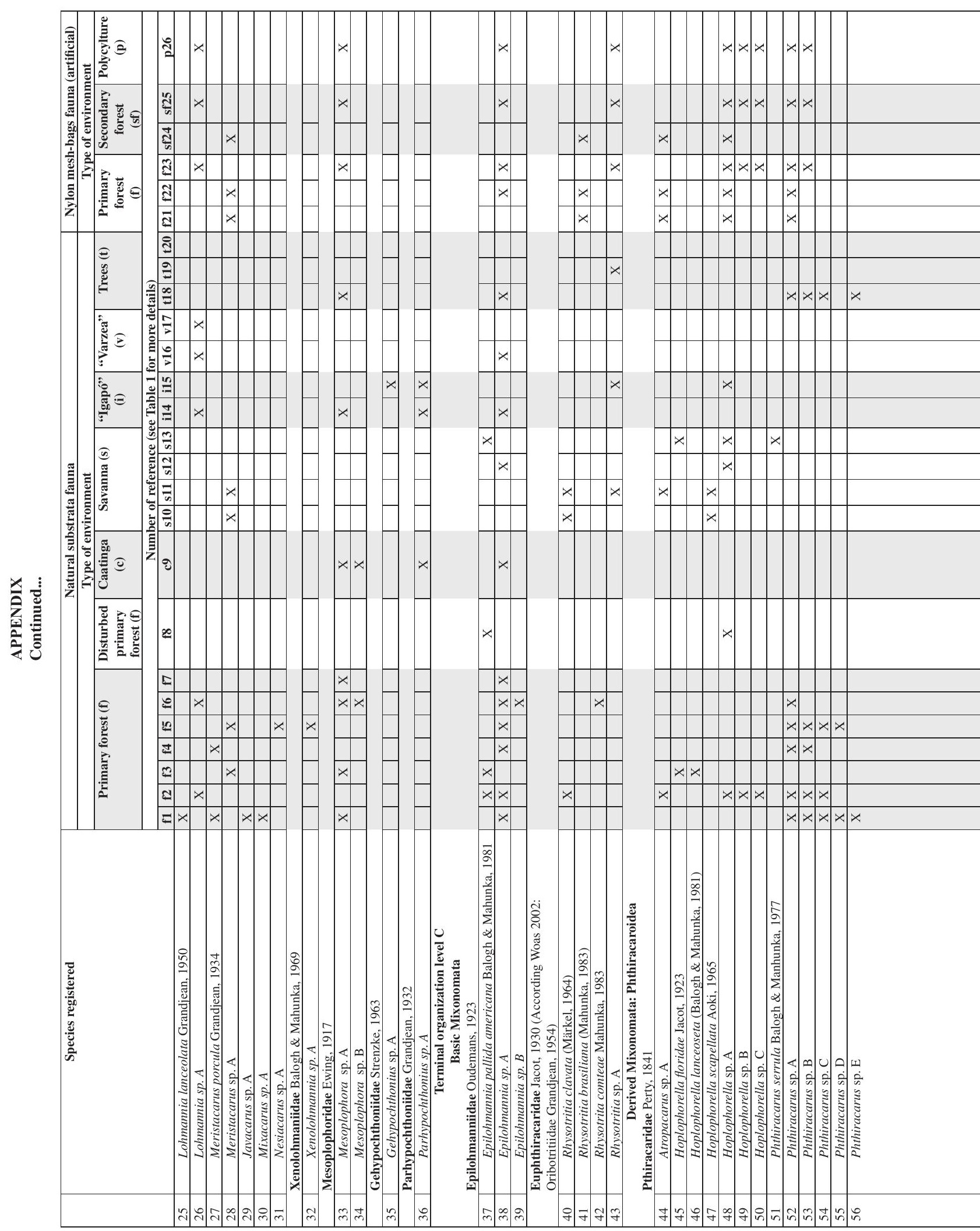




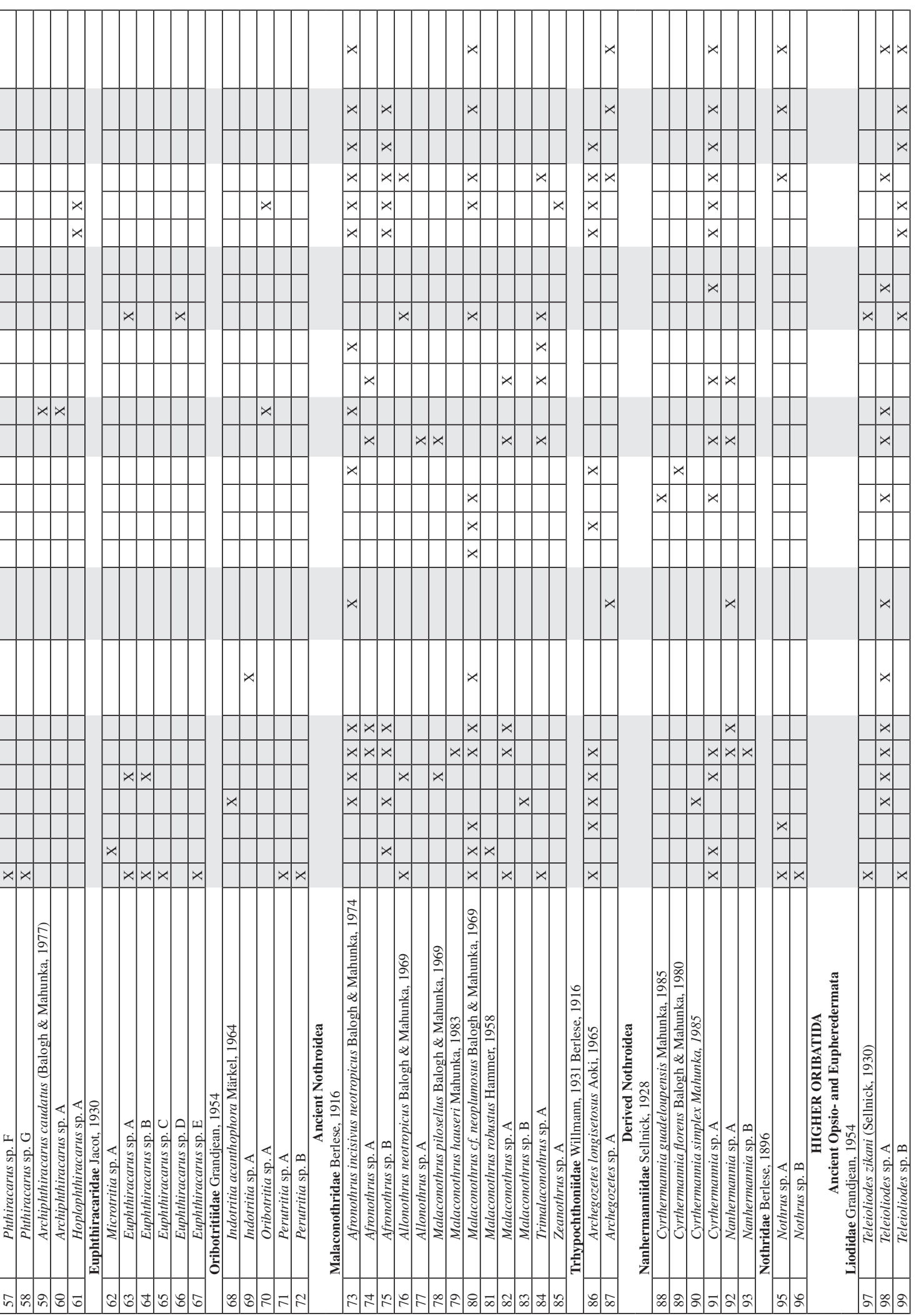




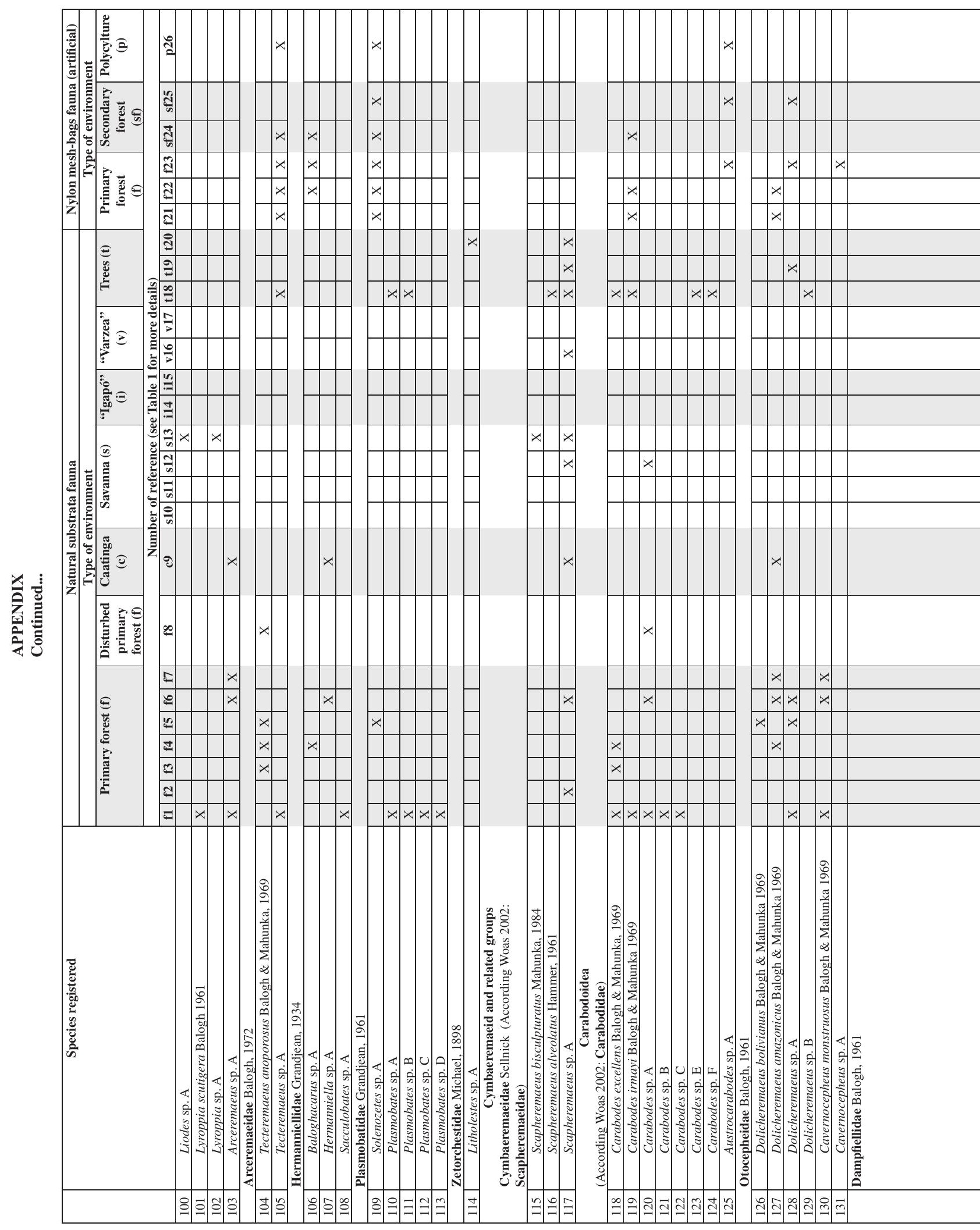




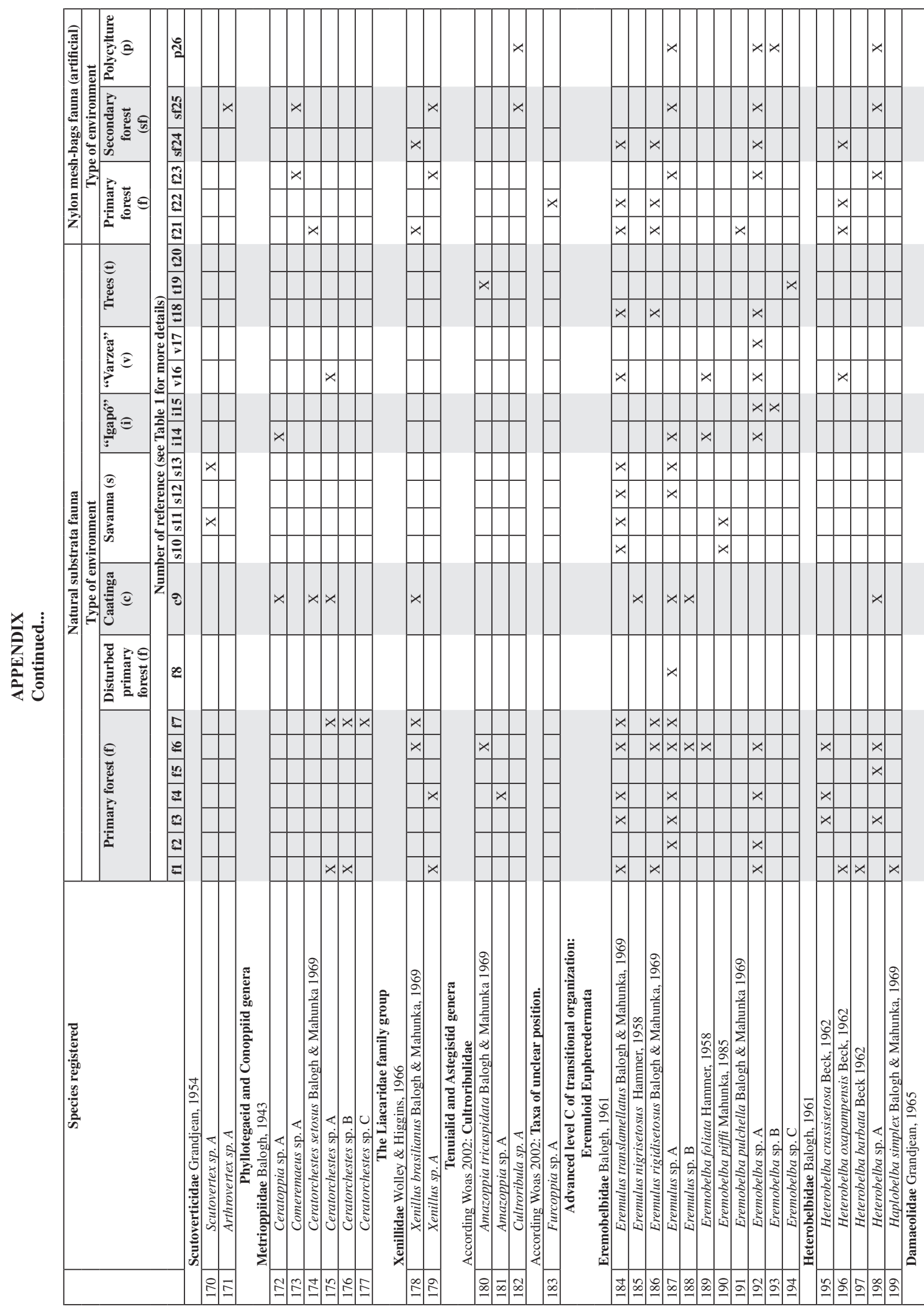




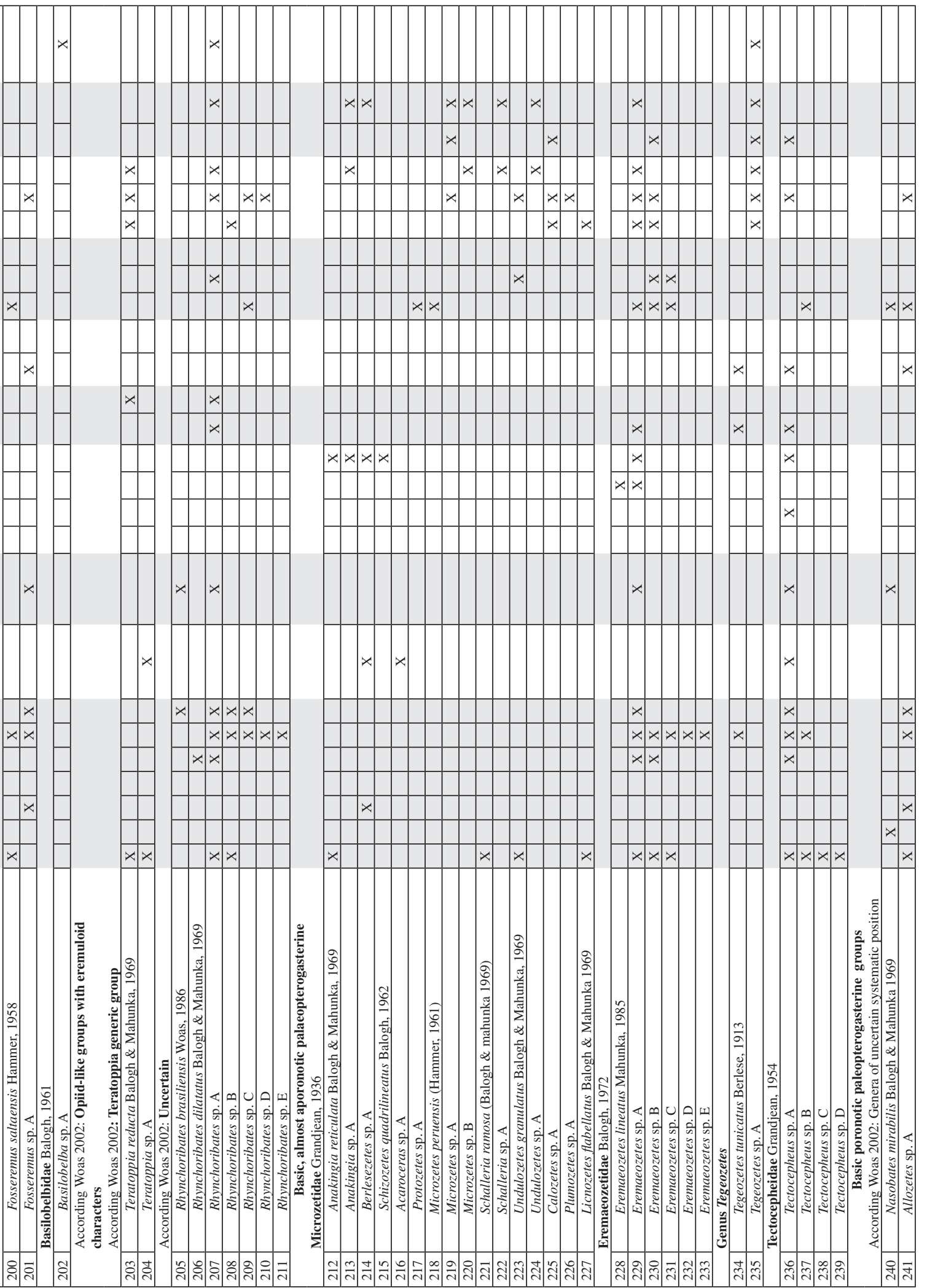




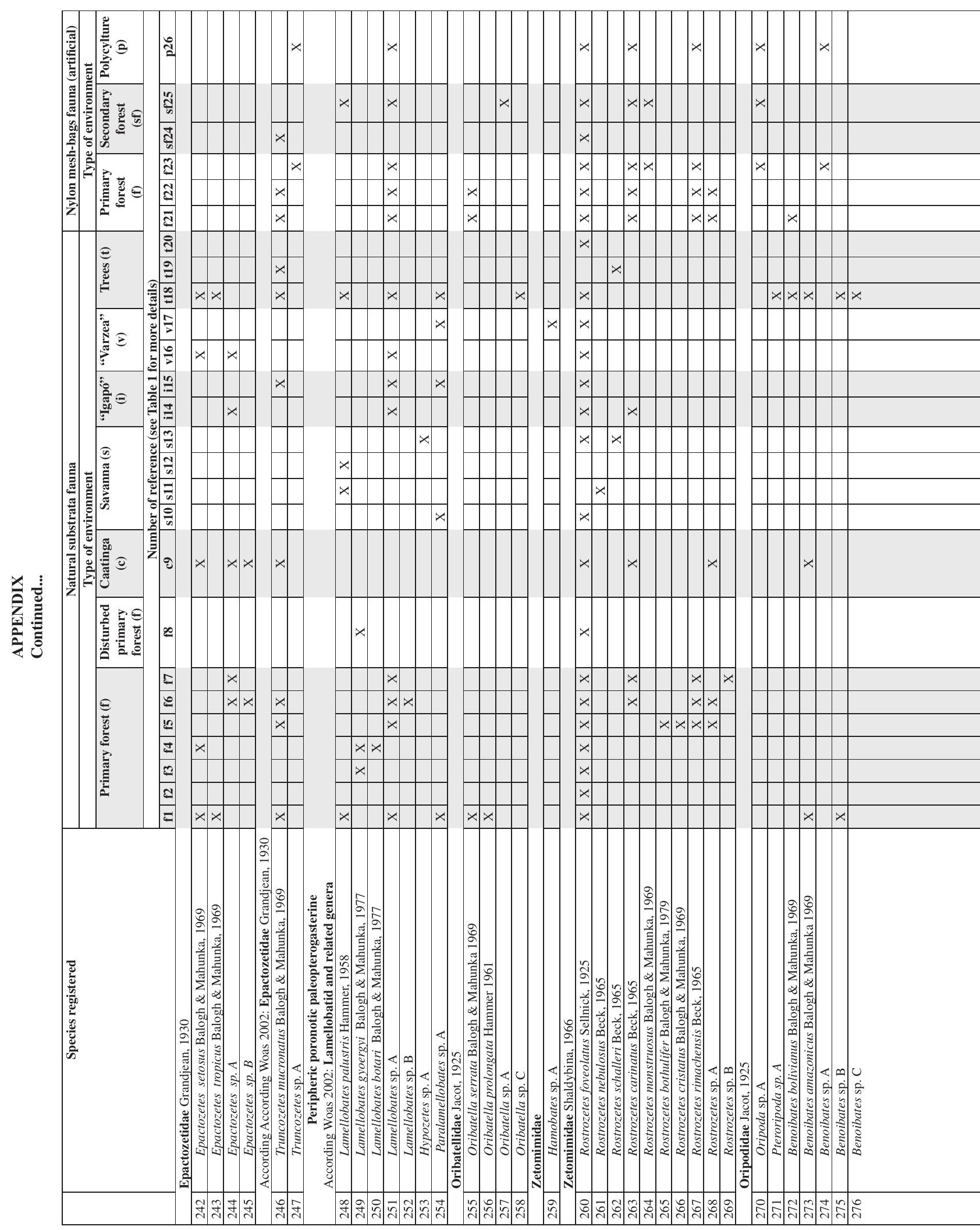




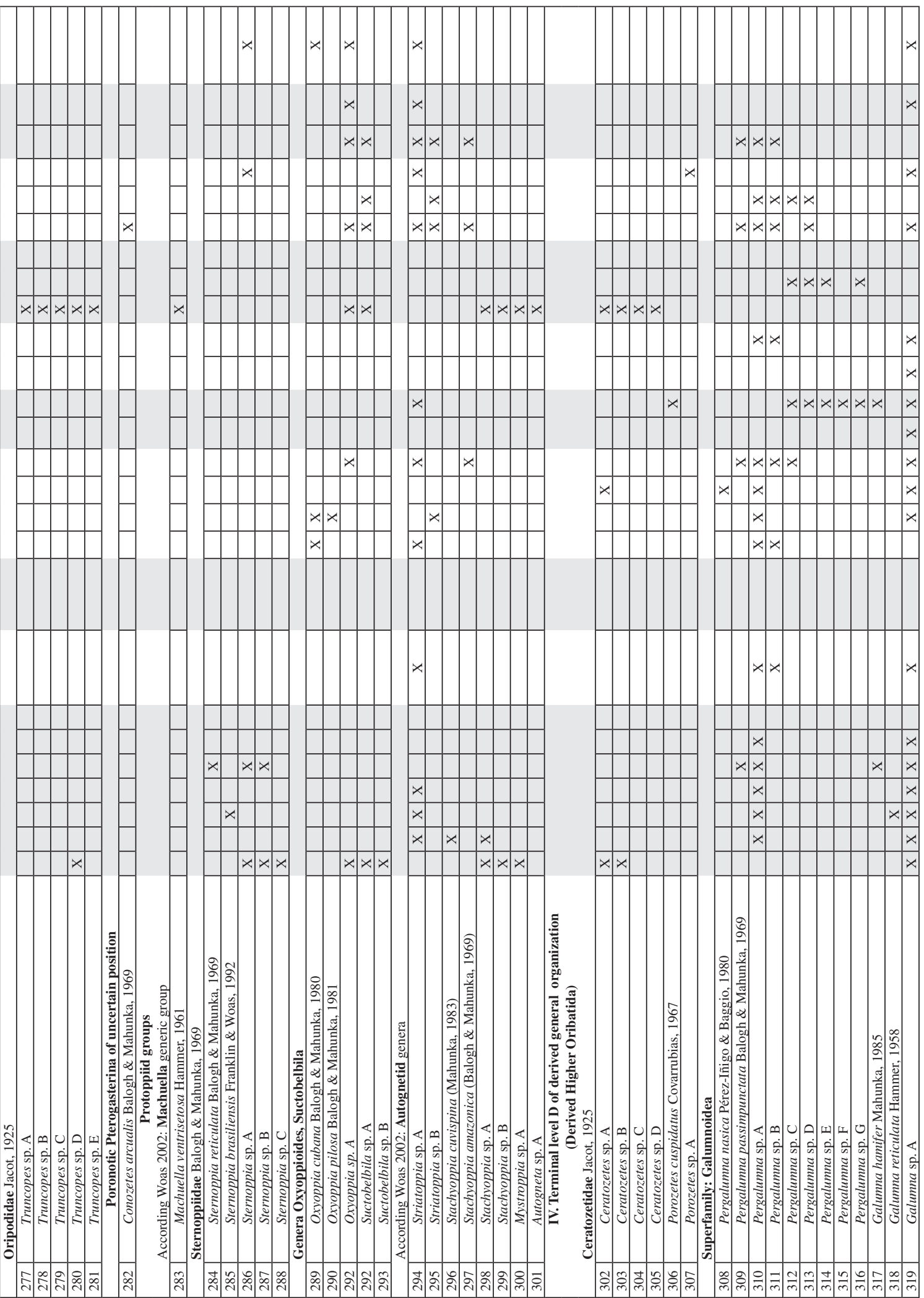




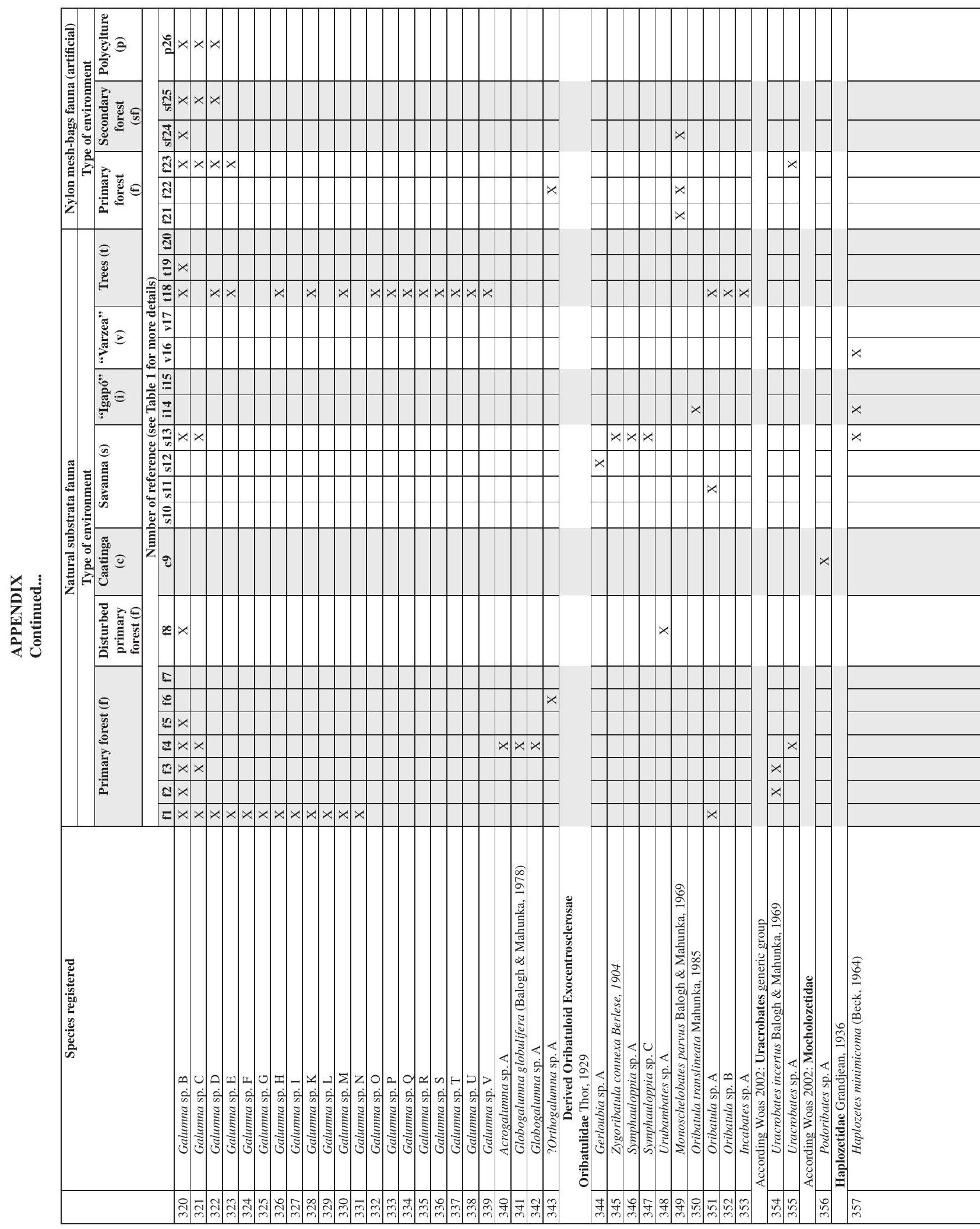




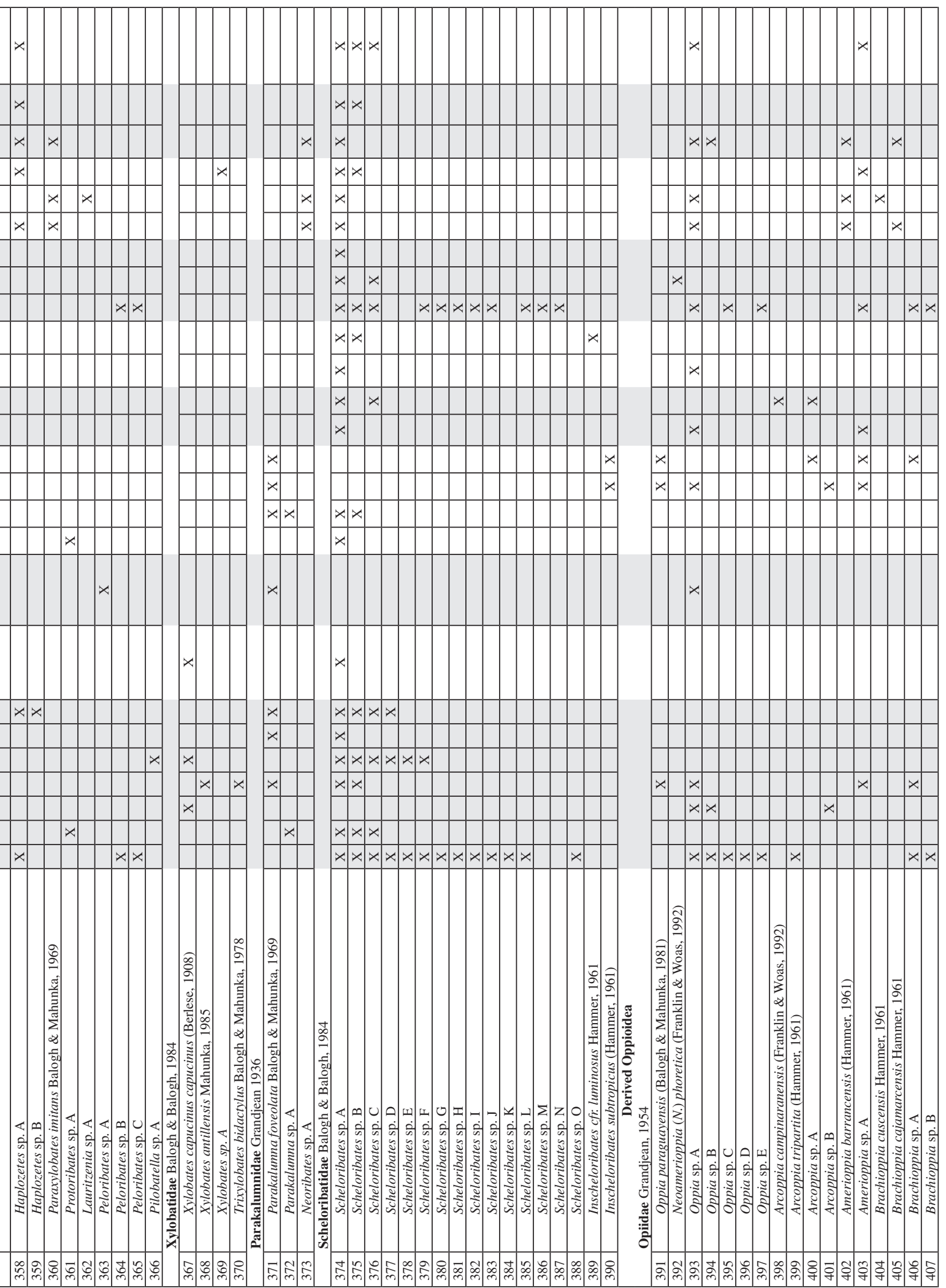




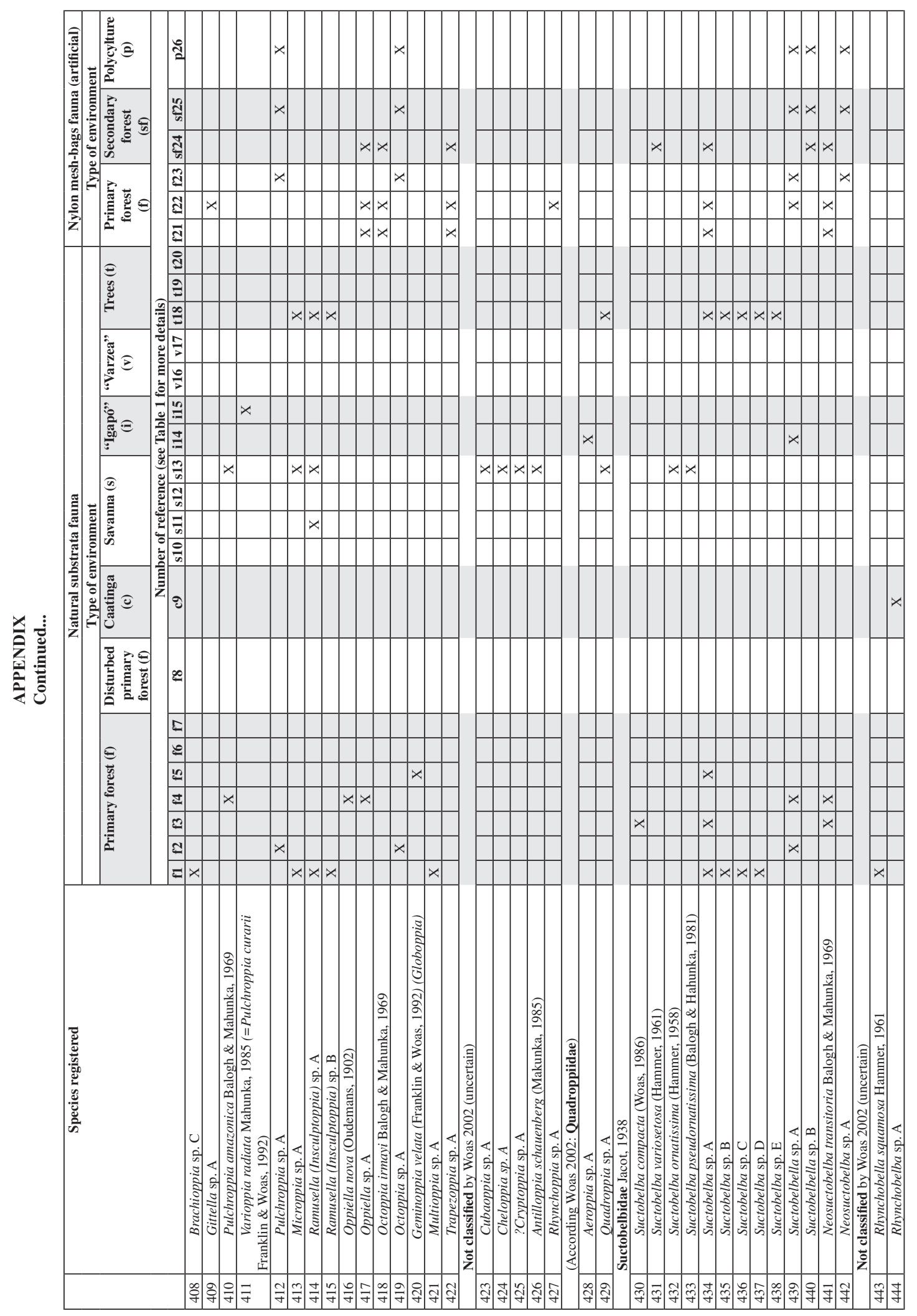

